\title{
PEMANFAATAN GLISEROL SEBAGAI LIMBAH BIODIESEL MELALUI PROSES BIOLOGIK 1: PEMILIHAN MIKROBA
}

\author{
R. Purwadi, M.T.A.P. Kresnowati*, L. Badriyah, Andini A. D. Puri, R. Aisyah \\ Kelompok Keahlian Perancangan dan Pengembangan Produk Teknik Kimia \\ Fakultas Teknologi Industri, Institut Teknologi Bandung \\ Jalan Ganesha 10, Bandung 40132 \\ Email: kresnowati@che.itb.ac.id
}

\begin{abstract}
Abstrak
Ketersediaan gliserol, produk samping industri biodiesel, semakin meningkat seiring pertumbuhan industri biodiesel. Meskipun gliserol murni banyak digunakan dalam industri makanan, farmasi, kosmetik, dan industri-industri lainnya, pemurnian limbah gliserol menjadi gliserol murni sangat mahal dan tidak efektif. Studi literatur menunjukkan bahwa beberapa jenis mikroba dapat menggunakan gliserol sebagai substratnya. Hal ini menjadi dasar untuk menerapkan proses pengolahan gliserol menjadi produk bermanfaat melalui proses mikrobiologik. Makalah ini menyajikan hasil penelitian eksplorasi potensi mikroba dalam mengkonversi gliserol murni dalam substrat, yang merupakan tahap awal dari rangkaian penelitian pemanfaatan limbah gliserol melalui proses mikrobiologik. Dalam penelitian ini diteliliti kemampuan mikroba Aerobacter aerogenes ITBCC B88, Klebsiella pneumoniae ITBCC113, dan Enterobacter cloacae NRLL B411, NRLL B23264, dan NRLL B23289 dalam memanfaatkan gliserol. Penelitian yang dilakukan meliputi uji pertumbuhan pada substrat gliserol murni dan kondisi aerobik, dengan memvariasikan konsentrasi gliserol dan nisbah $\mathrm{C} / \mathrm{N}$ dalam media. Hasil penelitian menunjukkan semua mikroba uji dapat tumbuh dengan baik pada substrat gliserol dan mengasimilasi gliserol lebih baik pada nisbah $\mathrm{C} / \mathrm{N}$ media yang lebih rendah. Namun demikian peningkatan konsumsi gliserol selama proses kultivasi tidak diikuti oleh peningkatan perolehan biomassa, yang mengindikasikan terjadinya pembentukan produk-produk metabolit oleh mikroba.
\end{abstract}

Kata kunci: gliserol, biodiesel, Aerobacter aerogenes, Klebsiella pneumoniae, Enterobacter cloacae

\section{Abstract}

UTILIZATION OF GLYCEROL BIODIESEL WASTE VIA BIOLOGICAL PROCESS 1: SELECTION OF MICROBES. The availability of glycerol, a byproduct of biodiesel production, is increasing along with the growth of biodiesel industries. While glycerol is used in various industries such as food, pharmaceutical, and cosmetics, the purification of crude glycerol from biodiesel waste can be very costly and inefficient. Literature study indicated that some microorganism could utilize glycerol as their substrate. This forms the basis for applying microbial conversion of glycerol into valuable products. This paper presents our study in exploring the microbial potentials in utilizing pure glycerol as substrate, which is a part of a larger study in converting crude glycerol from biodiesel waste through microbial processes. In this study the potentials of Aerobacter aerogenes ITBCC B88, Klebsiella pneumoniae ITBCC113, and Enterobacter cloacae NRLL B411, NRLL B23264, and NRLL B23289 in utlizing glycerol were explored. The study covered the aerobic growth tests of each strain using glycerol as $\mathrm{C}$-source in substrate, by varying glycerol concentration and $\mathrm{C} / \mathrm{N}$ ratio in the media. The results indicated that all the tested strains could grow well in glycerol and would assimilate glycerol better in low $\mathrm{C} / \mathrm{N}$ ratio. However, the increase in microbial glycerol consumption did not increase the biomass yield, which might indicate the production of metabolic products.

Keywords: glycerol, biodiesel, Aerobacter aerogenes, Klebsiella pneumoniae, Enterobacter cloacae

*penulis korespondensi 


\section{PENDAHULUAN}

Pengembangan sumber energi alternatif mutlak diperlukan untuk mengatasi keterbatasan minyak bumi. Pemerintah Indonesia telah bertekad untuk mengurangi ketergantungan negara terhadap minyak dan mencanangkan penggunaan sumber daya alam terbarukan untuk memproduksi energi. Dalam Cetak Biru Manajemen Energi Nasional, pemerintah Indonesia menargetkan sumber daya terbarukan akan memiliki kontribusi sebesar 4\% terhadap kebutuhan kelistrikan negara pada tahun 2025. Cetak Biru Manajemen Energi Nasional juga menargetkan penggunaan biodiesel, sebagai salah satu alternatif sumber energi, sebesar 4,7 juta kiloliter pada tahun 2025 (DESDM, 2003). Hal ini menunjukkan bahwa peran biodiesel dalam pemenuhan kebutuhan kelistrikan negara sangatlah penting.

Biodiesel merupakan hasil reaksi transesterifikasi minyak nabati dengan metanol dalam suatu kondisi tekanan dan suhu tertentu dengan menggunakan katalis basa. Reaksi transesterifikasi ini menghasilkan senyawa ester metil asam lemak yang merupakan biodiesel itu sendiri dan gliserol sebagai produk samping atau limbahnya. Untuk sembilan kilogram biodiesel yang dihasilkan, akan dihasilkan sekitar satu kilogram crude glycerol sebagai produk samping.

Seiring meningkatnya produksi biodiesel, gliserol yang dihasilkan akan semakin melimpah. Namun, gliserol yang dihasilkan melalui proses ini memiliki nilai ekonomi yang rendah karena masih mengandung pengotor-pengotor. Akibat masih ditemukannya pengotor dalam gliserol, dibutuhkan perlakuan awal untuk mengolah gliserol yang bernilai ekonomi rendah menjadi gliserol yang bernilai tinggi. Di lain pihak, melimpahnya ketersediaan gliserol mengakibatkan turunnya nilai jual bahan tersebut. Dengan demikian pemurnian gliserol sebagai hasil samping produksi biodiesel menjadi tidak ekonomis untuk dilakukan. Sementara itu, gliserol ini tidak bisa langsung dibuang ke lingkungan karena kandungan bahan organiknya yang tinggi. Oleh karena itu, diperlukan suatu penelitian untuk mencari pengolahan limbah gliserol menjadi produk lain yang lebih potensial.

Pengolahan gliserol menjadi produk yang berguna dapat dilakukan dengan berbagai macam cara, di antaranya dengan menggunakan katalis kimia melalui proses gliserol hidrogenolisis menjadi produk 1,2propanadiol (Miyazawa dkk., 2007). Gliserol juga dapat dikonversi menjadi dihidroksiaseton melalui proses oksidasi fasa cair dengan udara menggunakan katalis platinum pada $\mathrm{pH}$ tertentu (Garcia dkk., 1995). Hidrogen yang saat ini diusulkan untuk menjadi bahan bakar terbarukan generasi mendatang juga dapat diproduksi melalui proses steam reforming gliserol pada fasa gas dengan menggunakan katalis ruthenium (Hirai dkk., 2005). Poligliserol yang digunakan sebagai bahan antifogging dan antistatik atau minyak pelumas dapat diperoleh melalui proses eterifikasi gliserol (Clacens dkk., 2002).

Pengolahan gliserol juga dapat dilakukan melalui proses biologik dengan menggunakan bantuan mikroorganisme. Dalam proses ini, gliserol dalam substrat digunakan sebagai sumber energi dan sumber karbon. Beberapa contoh mikroorganisme yang mampu hidup dengan menggunakan substrat gliserol adalah Aerobacter aerogenes, Anaerobiospirillum succiniciproducens, Clostridium butyricum, Clostridium acetobutylicum, Eschericia coli, Klebsiella pneumeniae, Paenibacillus macerans dan Lactobacillus sp. (Magasanik dkk., 1953; Clomburg dan Gonzales, 2013; Dobson dkk., 2012). Mikroorganisme-mikroorganisme tersebut dapat mengkonversi gliserol menjadi berbagai macam produk seperti biohidrogen, laktat, etanol, butanol, 1,3-propanadiol, 1,2propanadiol, 3-hidroksipropionaldehida, asam format, asam sitrat, asam propionat, dan asam suksinat.

Penelitian ini bertujuan untuk mengembangkan proses mikrobiologik untuk mengolah limbah pabrik biodiesel menjadi produk-produk yang bernilai. Pada tahap pertama dilakukan pemilihan strain mikroba yang sesuai dengan kriteria dapat mengasimilasi gliserol, dengan baik dan menghasilkan produk yang bernilai. Walaupun sudah dilaporkan bahwa berbagai mikroba dapat memanfaatkan gliserol, namun pada kenyataannya tidak semua strain dari spesies mikroba tersebut dapat menggunakan gliserol sebagai sumber energi dan sumber karbonnya. Oleh karena itu penelitian ini dilakukan untuk menjawab pertanyaan apakah spesies mikroba yang digunakan dalam percobaan ini, Aerobacter aerogenes ITBCC B88, Klebsiella pneumoniae 
ITBCC113, dan Enterobacter cloacae NRLL B411, NRLL B23264, dan NRLL B23289, mampu menggunakan gliserol sebagai substratnya dan mengolahnya menjadi produk yang bermanfaat. Artikel ini membahas potensi pertumbuhan strain-strain mikroba tersebut pada substrat gliserol. Untuk memperoleh gambaran yang lebih jelas, percobaan dilakukan pada berbagai konsentrasi gliserol substrat dan pada berbagai perbandingan karbon terhadap nitrogen di dalam substrat. Potensi produk metabolit yang dihasilkan akan disampaikan pada tulisan yang terpisah.

\section{METODE}

\section{Mikroorganisme dan Media Kultivasi}

Mikroorganisme yang digunakan dalam penelitian ini adalah Aerobacter aerogenes ITBCC B88 dan Klebsiella pneumoniae ITBCC113 yang diperoleh dari Koleksi Kultur ITB (Laboratorium Mikrobiologi dan Teknologi Bioproses Program Studi Teknik Kimia ITB) serta Enterobacter cloacae NRLL B411, Enterobacter cloacae NRLL B23264, dan Enterobacter cloacae NRLL B23289. Mikroorganisme-mikroorganisme tersebut dikultivasi menggunakan medium dengan komposisi $\mathrm{Na}_{2} \mathrm{HPO}_{4}$ 0,54\%; $\mathrm{KH}_{2} \mathrm{PO} 4$ 1,26\%; $\mathrm{MgSO}_{4} .7 \mathrm{H}_{2} \mathrm{O}$ 0,02\%; $\mathrm{CaCl}_{2}$ 0,001\%; $\left(\mathrm{NH}_{4}\right)_{2} \mathrm{SO}_{4}$ $0,2 \%$, dan pH 6,5 (Magasanik dkk., 1953). Tripton dan ekstrak ragi (yeast extract) juga ditambahkan ke dalam larutan medium sebesar masing-masing 5 gram/liter larutan. Komposisi gliserol pada medium disesuaikan dengan desain setiap tempuhan. Medium disterilisasi pada suhu $121{ }^{\circ} \mathrm{C}$ selama 15 menit.

\section{Proses Fermentasi}

Proses fermentasi dilakukan pada volume kerja $750 \mathrm{~mL}$ dalam labu Erlenmeyer 1 liter yang ditempatkan di atas rotary shaker pada suhu kamar dalam kondisi aerobik. Inokulum yang ditambahkan adalah sebanyak $10 \%$ dari total volume kerja fermentasi yang digunakan. Konsentrasi gliserol dalam substrat divariasikan antara 0,5\% sampai 5\%, kecuali untuk Enterobacter cloacae yang ditumbuhkan hanya pada media gliserol $2 \%$. Adapun konsentrasi sumber Nitrogen dalam substrat, $\left(\mathrm{NH}_{4}\right)_{2} \mathrm{SO}_{4}$, juga divariasikan sedemikian rupa sehingga diperoleh nisbah C/N antara 3,1 sampai 9,6. Dalam setiap tempuhan diambil sampel secara periodik untuk analisis gliserol dan konsentrasi biomassa. Data yang diperoleh diolah untuk mendapatkan parameter perolehan biomassa yang dinyatakan dalam mg sel kering/mg gliserol dan konsumsi gliserol total.

\section{Metode Analisis}

Konsentrasi biomassa diukur dengan metode turbiditas menggunakan spektrofotometer pada panjang gelombang $600 \mathrm{~nm}$. Berat kering sampel diperoleh melalui proses sentrifugasi dan pengeringan dengan oven pada suhu $70{ }^{\circ} \mathrm{C}$ sampai diperoleh berat yang konstan. Konversi nilai absorbansi menjadi berat kering dilakukan menggunakan kurva kalibrasi.

Konsentrasi gliserol diukur dengan metode titrasi menggunakan asam periodat (Bradford dkk., 1942). Pada metode ini gugus hidroksil yang berdekatan pada gliserol akan dioksidasi oleh asam periodat menjadi asam format. Asam periodat yang tersisa dikuantifikasi melalui titrasi asam basa dengan $\mathrm{NaOH}$. Tingkat utilisasi gliserol oleh mikroba diukur dengan penurunan konsentrasi gliserol dalam larutan fermentasi dan parameter perolehan biomassa $\mathrm{Y}_{\mathrm{sX}}[\mathrm{mg}$ sel/mg gliserol]) yang didefinisikan sebagai perbandingan konsentrasi sel yang diproduksi terhadap konsentrasi gliserol yang dikonsumsi.

\section{HASIL DAN PEMBAHASAN \\ Pengaruh Variasi Konsentrasi Gliserol terhadap Pertumbuhan Mikroba}

Komposisi sumber mikronutrien pada medium pertumbuhan untuk mikroba Aerobacter aerogenes, K.pneumonia, dan Enterobacter cloacae disiapkan mengikuti komposisi dalam literatur (Magasanik dkk., 1953). Konsentrasi gliserol sebagai sumber karbon divariasikan untuk melihat pengaruhnya pada pertumbuhan mikroba tersebut. Gliserol dapat diasimilasi secara efektif oleh Aerobacter aerogenes hingga konsentrasi 3\% (Gambar 1 dan Tabel 1). Pada konsentrasi gliserol $3 \%$ ini diperoleh konsentrasi biomassa yang maksimum dengan penurunan gliserol sebesar 33,3\% dalam waktu 60 jam. Perolehan biomassa yang dihasilkan pada kondisi ini sebesar 0,5 mg sel/mg gliserol. Pada konsentrasi gliserol yang lebih tinggi (5\%), penurunan konsentrasi gliserol lebih kecil dan biomassa yang diperoleh lebih sedikit. Tidak teramati suatu pola tertentu pada penurunan konsentrasi gliserol pada berbagai konsentrasi awal 
gliserol (Tabel 1), walaupun demikian terlihat tingkat perolehan biomassa semakin kecil pada konsentrasi awal gliserol yang semakin besar. Hal ini mengindikasikan bahwa gliserol yang dikonsumsi tidak hanya digunakan untuk pertumbuhan biomassa.

Tabel 1 juga menunjukkan bahwa terdapat perbedaan yang cukup signifikan antara desain konsentrasi gliserol pada substrat dengan konsentrasi gliserol awal hasil analisis. Hal ini dapat disebabkan antara lain oleh sifat gliserol yang higroskopik sehingga penyimpanan zat, penimbangan, dan penyiapan substrat perlu mendapatkan perhatian khusus.

Gliserol juga dapat diasimilasi secara efektif oleh Klebsiella pneumoniae hingga konsentrasi 2\% (Gambar 2 dan Tabel 2). Konsumsi gliserol paling baik tercapai pada konsentrasi gliserol $2 \%$ dengan penurunan gliserol sebesar 31,7 \% dalam waktu 58 jam. Perolehan biomassa yang dihasilkan pada kondisi ini sebesar $0,7 \mathrm{mg}$ sel/mg gliserol. Pada konsentrasi gliserol lebih besar dari $2 \%$,

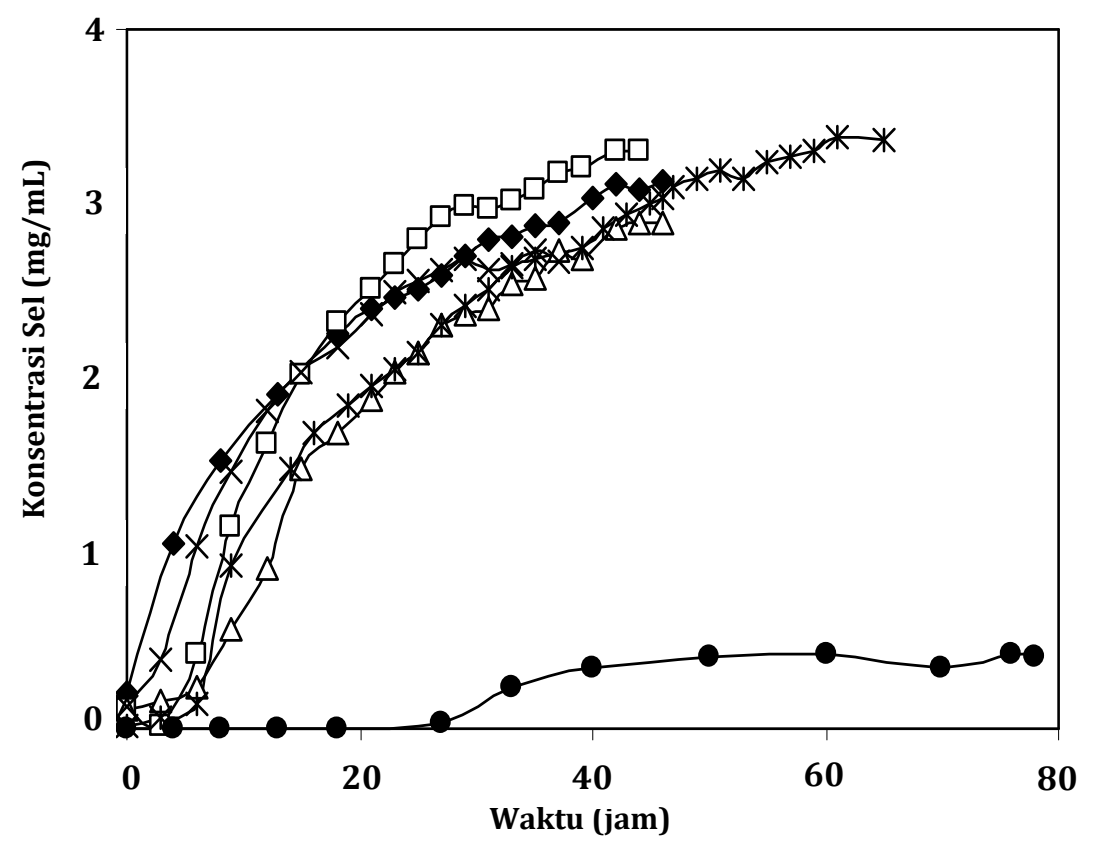

Gambar 1. Kurva pertumbuhan Aerobacter aerogenes pada berbagai konsentrasi gliserol dalam substrat: $0.5 \%(\diamond), 1 \%(\square), 1.5 \%(\triangle), 2 \%(X), 3 \%(*), 5 \%(\bullet)$

Tabel 1. Penurunan Konsentrasi Gliserol oleh Aerobacter aerogenes pada Tempuhan Percobaan dengan Konsentrasi Gliserol yang Divariasikan

\begin{tabular}{ccccc}
\hline $\begin{array}{c}\text { Desain } \\
\text { konsentrasi } \\
\text { gliserol } \\
\text { substrat } \\
\text { (\%-b) }\end{array}$ & $\begin{array}{c}\text { Konsentrasi } \\
\text { gliserol awal } \\
\text { hasil analisis } \\
\text { (\%-b) }\end{array}$ & $\begin{array}{c}\text { Konsentrasi } \\
\text { gliserol } \\
\text { akhir hasil } \\
\text { analisis } \\
\mathbf{( \% - b )}\end{array}$ & $\begin{array}{c}\text { Penurunan } \\
\text { konsentrasi } \\
\text { gliserol (\%) }\end{array}$ & $\begin{array}{c}\mathbf{Y}_{\mathbf{s x}} \\
\text { (mg sel/mg } \\
\text { gliserol) }\end{array}$ \\
\hline 0,5 & 0,8 & 0,6 & $25,0 \%$ & 1,6 \\
1,0 & 1,4 & 0,9 & $35,7 \%$ & 0,7 \\
1,5 & 2,1 & 1,8 & $14,3 \%$ & 1,0 \\
2,0 & 1,7 & 1,4 & $17,6 \%$ & 0,9 \\
3,0 & 2,1 & 1,4 & $33,3 \%$ & 0,5 \\
5,0 & 2,7 & 2,6 & $3,7 \%$ & 0,4 \\
\hline
\end{tabular}




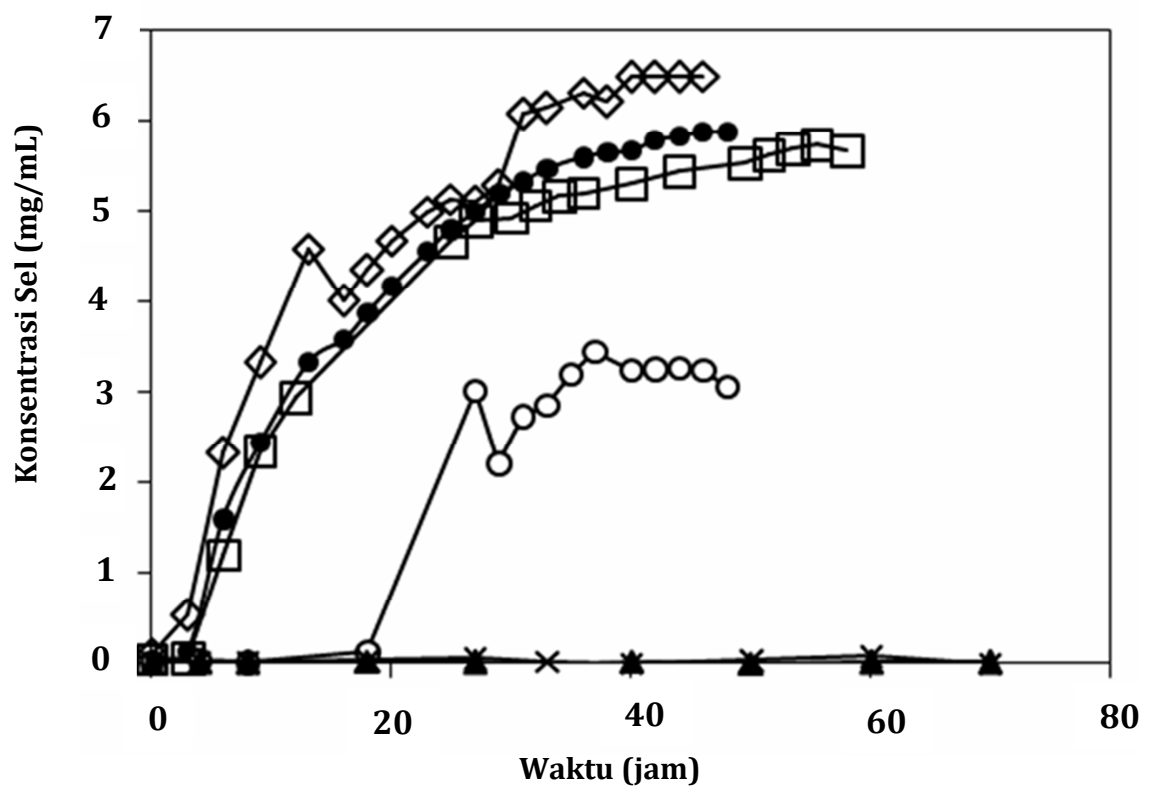

Gambar 2. Kurva pertumbuhan Klebsiella pneumoniae pada berbagai konsentrasi gliserol dalam substrat: $0.5 \%(\diamond), 1 \%(\bullet), 1.5 \%(O), 2 \%(\square), 3 \%(x), 5 \%(\Delta)$

Tabel 2. Penurunan Konsentrasi Gliserol oleh Klebsiella pneumoniae pada Tempuhan Percobaan dengan Konsentrasi Gliserol yang Divariasikan

\begin{tabular}{ccccc}
\hline $\begin{array}{c}\text { Desain } \\
\text { konsentrasi } \\
\text { gliserol } \\
\text { subsrat } \\
(\%-b)\end{array}$ & $\begin{array}{c}\text { Konsentrasi } \\
\text { gliserol awal } \\
\text { hasil analisis } \\
(\%-b)\end{array}$ & $\begin{array}{c}\text { Konsentrasi } \\
\text { gliserol } \\
\text { akhir hasil } \\
\text { analisis } \\
\text { (\%-b) }\end{array}$ & $\begin{array}{c}\text { Penurunan } \\
\text { konsentrasi } \\
\text { gliserol } \\
\text { (\%) }\end{array}$ & $\begin{array}{c}\text { Ysx } \\
\text { (mg sel/mg } \\
\text { gliserol) }\end{array}$ \\
\hline 0,5 & 1,6 & 1,5 & $6,3 \%$ & 6,3 \\
1 & 3,0 & 2,1 & $30,0 \%$ & 0,6 \\
1,5 & 1,2 & 1,2 & $0,0 \%$ & - \\
2 & 4,1 & 2,8 & $31,7 \%$ & 0,7 \\
3 & 2,4 & 2,3 & $4,2 \%$ & 0,0 \\
\hline
\end{tabular}

kemampuan asimilasi Klebsiella pneumoniae menurun dengan meningkatnya konsentrasi gliserol dalam umpan.

Untuk menyederhanakan tempuhan, ketiga jenis Enterobacter cloacae dikembangbiakkan dalam medium Magasanik dengan konsentrasi gliserol 2\% untuk melihat pertumbuhan yang terbaik (Gambar 3). Dari gambar tersebut, tampak bahwa Enterobacter cloacae NRLL B411 merupakan strain Enterobacter cloacae yang paling baik dalam menguraikan substrat gliserol, karena menghasilkan konsentrasi biomassa yang paling tinggi dibandingkan strain yang lain. Hal ini juga didukung dari data penelitian yang menunjukkan tingkat penurunan gliserol dari ketiga strain tersebut. Hasil pengukuran konsentrasi gliserol sebelum dan setelah proses fermentasi menunjukkan bahwa terjadi penurunan konsentrasi gliserol sebesar 20,4\% untuk Enterobacter cloacae NRLL B411, 8,8\% untuk Enterobacter cloacae NRLL B23264, dan 12,8\% untuk Enterobacter cloacae NRLL B23289. Pada tahapan selanjutnya hanya digunakan strain NRLL B411.

Terbatasnya asimilasi gliserol oleh strain-strain mikroorganisme tersebut di atas dapat diakibatkan oleh beberapa hal, termasuk terbatasnya sumber nutrisi lain pada saat mikroba tumbuh. Kemungkinan penjelasan lain untuk terbatasnya asimilasi 
gliserol adalah inhibisi gliserol terhadap pertumbuhan mikroba, namun kemungkinan ini tidak menjadi fokus pada penelitian ini.

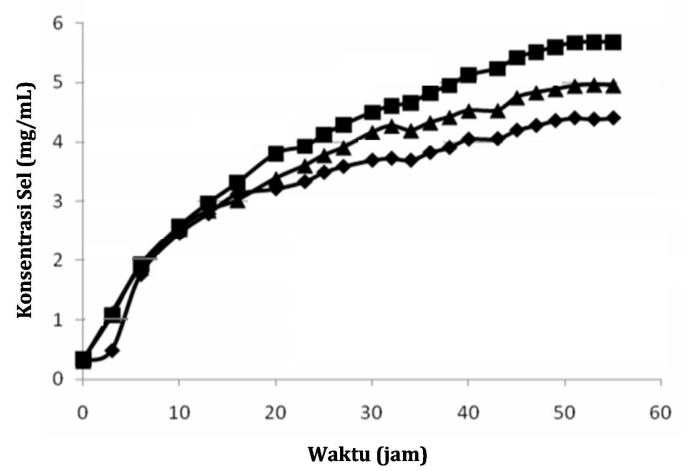

Gambar 3. Kurva pertumbuhan Enterobacter cloacae pada konsentrasi gliserol dalam substrat $2 \%$

Pengaruh variasi nisbah $\mathrm{C} / \mathrm{N}$ dalam medium terhadap pertumbuhan mikroba dan perolehan biomassa

Variasi nisbah $\mathrm{C} / \mathrm{N}$ dalam substrat bertujuan untuk melihat apakah ketersediaan gliserol, sebagai sumber karbon, merupakan faktor pembatas dalam pertumbuhan mikroba. Variasi $\mathrm{C} / \mathrm{N}$ dilakukan dengan menambahkan atau mengurangi komposisi ammonium sulfat pada konsentrasi gliserol tertentu. Dalam hal ini konsentrasi gliserol ditetapkan sebagai $2 \%$, yang pada percobaanpercobaan sebelumnya menghasilkan kombinasi tingkat perolehan biomassa dan laju pertumbuhan spesifik yang optimum (Tabel 1 dan 2).

Pada tempuhan percobaan menggunakan Aerobacter aerogenes, nisbah $\mathrm{C} / \mathrm{N}$ dinaikkan dari 6,0 sampai 9,6, atau dengan kata lain konsentrasi sumber Nitrogen dalam substrat diturunkan. Pertumbuhan mikroba tidak terlihat semakin baik ketika nisbah $\mathrm{C} / \mathrm{N}$ diturunkan (Gambar 4). Hal ini mengindikasikan bahwa komposisi Nitrogen dalam substrat memang menjadi pembatas. Data yang diperoleh tidak menunjukkan adanya suatu pola tertentu pada tingkat penurunan gliserol ketika nisbah $\mathrm{C} / \mathrm{N}$ dalam substrat divariasikan dan juga tidak terlihat pengaruh yang signifikan terhadap tingkat perolehan biomassa (Tabel 3).

Berdasarkan hasil tersebut, pada tempuhan percobaan selanjutnya yang menggunakan Klebsiella pneumoniae dan Enterobacter cloacae, nisbah C/N dalam substrat diturunkan dari 6,4 sampai dengan
3,2, atau dengan kata lain konsentrasi sumber Nitrogen dalam substrat dinaikkan.

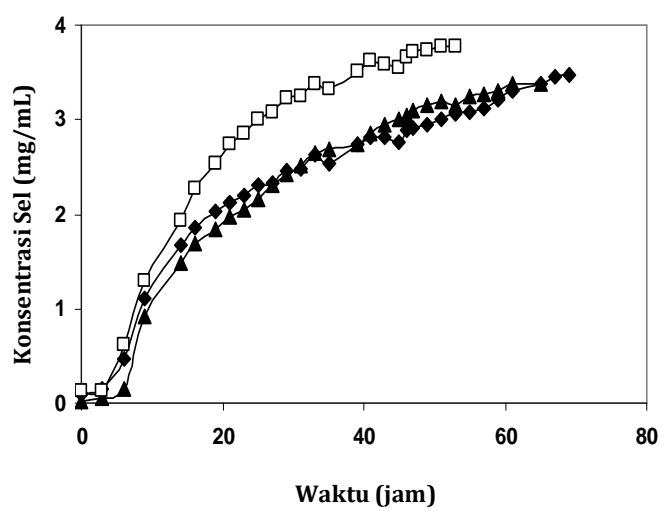

Gambar 4. Kurva pertumbuhan Aerobacter aerogenes pada berbagai nisbah $\mathrm{C} / \mathrm{N}: 6.02$ (ㅁ), $7.40(\diamond)$, dan 9.60 (A)

Pertumbuhan Klebsiella pneumoniae pada nisbah $\mathrm{C} / \mathrm{N}$ 4,93 terlihat lebih baik daripada pada nisbah C/N 6,40 (Gambar 5), walaupun pertumbuhannya pada nisbah $\mathrm{C} / \mathrm{N}$ 4,02 tidak sebaik yang diharapkan. Adapun pada Enterobacter cloacae terlihat jelas pertumbuhannya semakin baik pada nisbah $\mathrm{C} / \mathrm{N}$ yang semakin kecil atau pada konsentrasi sumber Nitrogen dalam substrat yang tinggi (Gambar 6). Hal ini menguatkan hipotesis sebelumnya bahwa konsentrasi Nitrogen dalam substrat merupakan faktor pembatas dalam rangkaian percobaan ini.

Pada Tabel 3, Tabel 4, dan Tabel 5 disajikan data-data pengaruh nisbah $\mathrm{C} / \mathrm{N}$ terhadap perolehan biomassa dan tingkat utilisasi gliserol pada ketiga strain mikroba yang diuji. Secara umum dapat dikatakan bahwa penurunan nisbah $\mathrm{C} / \mathrm{N}$ menyebabkan peningkatan konsumsi gliserol.

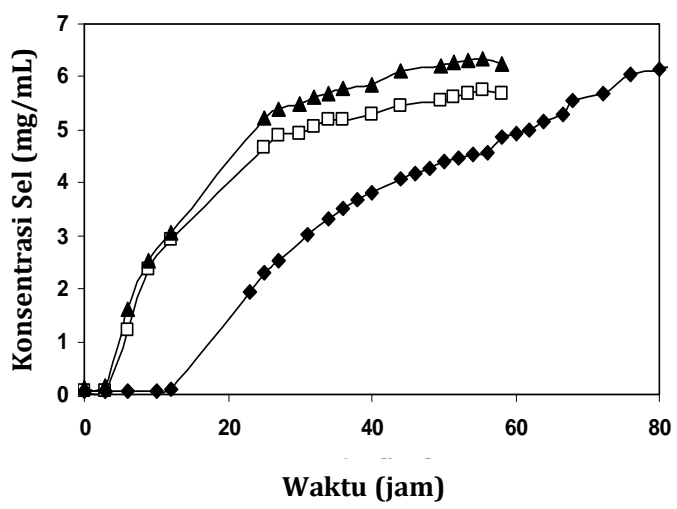

Gambar 5. Kurva pertumbuhan Klebsiella pneumoniae pada berbagai nisbah $\mathrm{C} / \mathrm{N}$ : $4.01(\diamond), 4.93(\Delta)$, dan $6.40(\square)$ 


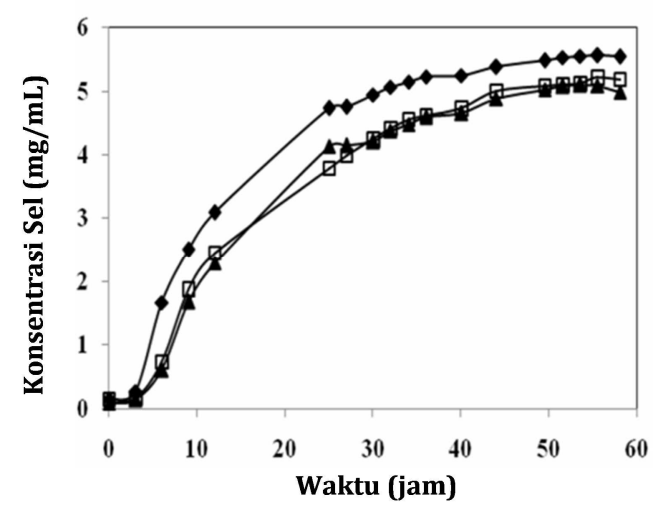

Gambar 6. Kurva pertumbuhan Enterobacter cloacae NRLL B411 pada berbagai nisbah C/N: $3.20(\diamond), 6.02(\square)$, dan $6.45(\Delta)$

Asimilasi gliserol maksimum oleh Aerobacter aerogenes dicapai pada konsentrasi gliserol 3\% dan nisbah C/N 6,02 dengan penurunan gliserol sebesar 41,7\%. Sedangkan, asimilasi gliserol maksimum oleh Klebsiella pneumoniae, dicapai pada konsentrasi gliserol 2\% dan nisbah C/N 4,02 dengan penurunan gliserol sebesar 50,0\%. Asimilasi gliserol maksimum oleh Enterobacter cloacae dicapai pada konsentrasi gliserol 2\% dan nisbah $\mathrm{C} / \mathrm{N} \quad 3,2$ dengan penurunan gliserol sebesar $63,6 \%$. Hal ini sejalan dengan pengamatan sebelumnya, bahwa pada percobaan yang dilakukan konsentrasi Nitrogen merupakan faktor pembatas pertumbuhan. Hal ini dikuatkan dengan hasil pengamatan yang menunjukkan bahwa peningkatan konsumsi gliserol tidak diikuti oleh peningkatan perolehan biomassa untuk ketiga jenis mikroba tersebut. Perolehan biomassa terhadap konsumsi gliserol tidak berubah secara signifikan pada tempuhan-tempuhan tersebut.

Tabel 3. Pengaruh Nisbah C/N terhadap Perolehan Biomassa Aerobacter aerogenes

\begin{tabular}{ccccc}
$\begin{array}{c}\text { Desain } \\
\text { nisbah C/N } \\
\text { tempuhan }\end{array}$ & $\begin{array}{c}\text { Konsentrasi } \\
\text { gliserol awal } \\
\text { hasil analisis } \\
\text { (\%-b) }\end{array}$ & $\begin{array}{c}\text { Konsentrasi } \\
\text { gliserol } \\
\text { akhir hasil } \\
\text { analisis } \\
\text { (\%-b) }\end{array}$ & $\begin{array}{c}\text { Penurunan } \\
\text { konsentrasi } \\
\text { gliserol } \\
\mathbf{( \% )}\end{array}$ & $\begin{array}{c}\mathbf{Y}_{\text {sx }} \\
\text { (mg sel/mg } \\
\text { gliserol) }\end{array}$ \\
\hline 6,02 & 2,4 & 1,4 & $41,7 \%$ & 0,1 \\
7,40 & 2,5 & 1,8 & $28,0 \%$ & 0,1 \\
9,60 & 2,1 & 1,4 & $33,3 \%$ & 0,1 \\
\hline
\end{tabular}

Tabel 4. Pengaruh Nisbah C/N terhadap Perolehan Biomassa Klebsiella pneumoniae

\begin{tabular}{ccccc}
$\begin{array}{c}\text { Desain } \\
\text { nisbah C/N } \\
\text { tempuhan }\end{array}$ & $\begin{array}{c}\text { Konsentrasi } \\
\text { gliserol awal } \\
\text { hasil analisis } \\
\text { (\%-b) }\end{array}$ & $\begin{array}{c}\text { Konsentrasi } \\
\text { gliserol } \\
\text { akhir hasil } \\
\text { analisis } \\
\text { (\%-b) }\end{array}$ & $\begin{array}{c}\text { Penurunan } \\
\text { konsentrasi } \\
\text { gliserol } \\
\mathbf{( \% )}\end{array}$ & $\begin{array}{c}\mathbf{Y}_{\text {sx }} \\
\text { (mg sel/mg } \\
\text { gliserol) }\end{array}$ \\
\hline 6,40 & 1,7 & 1,2 & $29,4 \%$ & 0,1 \\
4,93 & 1,5 & 1,0 & $33,3 \%$ & 0,1 \\
4,02 & 1,4 & 0,7 & $50,0 \%$ & 0,1 \\
\hline
\end{tabular}

Tabel 5. Pengaruh Nisbah C/N terhadap Perolehan Biomassa Enterobacter cloacae

\begin{tabular}{ccccc}
\hline $\begin{array}{c}\text { Desain } \\
\text { nisbah C/N } \\
\text { tempuhan }\end{array}$ & $\begin{array}{c}\text { Konsentrasi } \\
\text { gliserol awal } \\
\text { hasil analisis } \\
\text { (\%-b) }\end{array}$ & $\begin{array}{c}\text { Konsentrasi } \\
\text { gliserol } \\
\text { akhir hasil } \\
\text { analisis } \\
\text { (\%-b) }\end{array}$ & $\begin{array}{c}\text { Penurunan } \\
\text { konsentrasi } \\
\text { gliserol } \\
\text { (\%) }\end{array}$ & $\begin{array}{c}\text { Ysx } \\
\text { (mg sel/mg } \\
\text { gliserol) }\end{array}$ \\
\hline 6,46 & 2,3 & 2,6 & $-13,0 \%$ & - \\
6,02 & 2,3 & 1,9 & $17,4 \%$ & 0,1 \\
3,20 & 1,1 & 0,4 & $63,6 \%$ & 0,1 \\
\hline
\end{tabular}


Gliserol sebagai sumber karbon utama diasimilasi dalam keadaan aerobik oleh mikroorganisme sebagai sumber energi dan sumber bahan baku pembentuk sel (biomassa). Perubahan komposisi substrat dapat mengubah jalur metabolisma seperti yang ditunjukkan pada percobaan ini. Pada nisbah $\mathrm{C} / \mathrm{N}$ tinggi, yaitu jumlah sumberkarbon relatif jauh lebih besar dibandingkan dengan jumlah sumber nitrogen, asimilasi gliserol sangat lambat sehingga jumlah sel yang dihasilkan juga sedikit (lihat Tabel 3-5). Kondisi ini menyebabkan perolehan biomassa bernilai kecil untuk Aerobacter aerogenes, Klebsiella pneumoniae, dan Enterobacter cloacae yang mengindikasikan bahwa kedua jenis mikroba tersebut tidak tumbuh dengan baik. Hal ini mungkin disebabkan oleh gliserol dalam jumlah yang banyak dapat menginhibisi pertumbuhan kedua jenis mikroba tersebut. Kemungkinan lain yang menyebabkan hal tersebut adalah kurang mencukupinya nitrogen dan unsur-unsur pendukung pertumbuhan lain dalam medium sehingga biomassa tidak dapat terbentuk. Dapat dipahami bahwa untuk dapat mengasimilasi gliserol, sel harus mengubah alur metabolisma dan membangun enzimenzim yang dibutuhkan untuk asimilasi gliserol. Kurangnya pasokan nitrogen akan memaksa sel melakukan penataan ulang komponen sel agar asimilasi gliserol dapat berlangsung. Tentunya, sel akan tumbuh jauh lebih lambat dibandingkan jika sel ditumbuhkan dalam pasokan nitrogen yang cukup (lihat kurva pertumbuhan Aerobacter aerogenes dalam $5 \%$ gliserol pada Gambar 1 dan kurva pertumbuhan K.pneumonia dalam 3\% dan 5\% gliserol pada Gambar 2).

Secara teoritis, gliserol yang dikonsumsi dapat digunakan untuk menghasilkan biomassa, sehingga kenaikan konsumsi gliserol mempengaruhi kenaikan perolehan biomassa. Namun, dalam penelitian ini, peningkatan konsumsi gliserol tidak diikuti peningkatan perolehan biomassa. Hal ini diduga karena gliserol yang banyak terkonsumsi tersebut tidak hanya digunakan untuk memproduksi biomassa saja, melainkan memproduksi produk metabolik lain sehingga nilai perolehan biomassanya rendah.

Penelitian lebih lanjut perlu dilakukan untuk membuktikan terbentuknya produkproduk lain sebagai hasil konsumsi gliserol dari kedua jenis mikroba tersebut. Dengan adanya penelitian lanjutan, dapat diperoleh kondisi optimum (untuk variabel konsentrasi gliserol, nisbah $\mathrm{C} / \mathrm{N}$ dalam medium, dan kondisi pengudaraan tertentu) dalam produksi produk-produk yang komersil. Dengan mengetahui produk-produk bermanfaat yang dihasilkan, penelitian berikutnya akan menggunakan gliserol mentah sebagai limbah yang dihasilkan industri biodiesel.

Tingkat utilisasi gliserol yang teramati dalam penelitian ini berada pada rentang 0$63,6 \%$. Utilisasi gliserol tertinggi dicapai oleh Enterobacter cloacae pada konsentrasi gliserol $2 \%$ dan nisbah C/N 3,20. Tingkat utilisasi yang teramati ini relatif rendah. Studi literatur menunjukkan tingkat utilisasi gliserol sampai dengan 97\% oleh Clostrididum sp. (Forsberg dkk., 1987) dan bahkan mendekati 100\% oleh Enterobacter aerogenes (Ito dkk., 2005). Tingkat utilisasi gliserol yang tinggi ini diperoleh pada kondisi operasi anaerobik dan dengan menggunakan media yang lebih kompleks, di antaranya menggunakan berbagai jenis vitamin dan trace mineral. Kondisi kultivasi yang diterapkan, di antaranya meliputi komposisi media yang digunakan dan kondisi operasi $(\mathrm{pH}, \mathrm{T}$, dan pengudaraan), masih dapat dioptimalkan untuk mencapai tingkat utilisasi gliserol yang tinggi dan tingkat perolehan biomassa dan juga potensial produk yang lebih baik.

\section{KESIMPULAN}

Hasil penelitian ini menunjukkan semua mikroba uji, Aerobacter aerogenes ITBCCB88, Klebsiella pneumoniae ITBCC113, Enterobacter cloacae NRLL B411, Enterobacter cloacae NRLL B23264, dan Enterobacter cloacae NRLL B23289 merupakan mikroba yang potensial untuk digunakan dalam proses pengolahan gliserol. Seluruh mikroba uji dapat mengasimilasi gliserol dan tumbuh dengan baik pada substrat tersebut. Pada umumnya strainstrain tersebut tumbuh optimal pada kisaran konsentrasi awal gliserol 2\%. Penurunan nisbah $\mathrm{C} / \mathrm{N}$ pada media akan meningkatkan tingkat asimilasi gliserol. Namun demikian peningkatan asimilasi gliserol ini tidak diikuti oleh peningkatan perolehan biomassa dari gliserol.

\section{DAFTAR PUSTAKA}

Bradford, P.; Pohle, W. D.; Gunther, J. K.; Mehlenbacher, V. C., Determination of glycerol by oxidation with periodic acid, Journal of the 
American Oil Chemists' Society, 1942, 19(11), 189-193.

Clacens, J. M.; Pouilloux, Y.; Barrault, J., Selective etherification of glycerol to polyglycerols over impregnated basic MCM-41 type mesoporous catalysts, Applied Catalysis A: General, 2002, 227(1-2), 181-190.

Clomburg, J. M.; Gonzales, R., Anaerobic fermentation of glycerol: a platform for renewable fuels and chemicals, Trends in Biotechnology, 2013, 31(1), 20-28.

Departemen Energi dan Sumber Daya Mineral, Kebijakan Pengembangan Energi Terbarukan dan Konservasi Energi. 2003, http:// www.esdm.go.id (akses 2012).

Dobson, R.; Gray, V.; Rumbold, K., Microbial utilization of crude glycerol for the production of value-added products, Journal of Industrial Microbiology and Biotechnology, 2012, 39(2), 217-226.

Forsberg, C. W., Production of 1,3-propanediol from glycerol by Clostridium acetobutylicum and other clostridium species, Applied and Environmental Microbiology, 1987, 53(4), 639-643.
Garcia, R.; Besson, M.; Gallezot, P., Chemoselective catalytic oxidation of glycerol with air on platinum metals, Applied Catalysis A: General, 1995, 127(1-2), 165-176.

Hirai, T.; Ikenaga, N. O.; Miyake, T.; Suzuki, T., Production of hydrogen by steam reforming of glycerin on ruthenium catalyst. Energy and Fuels, 2005, 19(4), 1761-1762.

Ito, T.; Nakashimada, Y.; Senba, K.; Matsui, T.; Nishio, N., Hydrogen and ethanol production from glycerol-containing wastes discharged after biodiesel manufacturing process, Journal of Bioscience and Bioengineering, 2005, $100(3), 260-265$.

Magasanik, B.; Brooke, M.S.; Karibian, D., Metabolic pathways of glycerol dissimilation: a comparative study of two galurs of Aerobacter aerogenes, Journal of Bacteriology, 1953, 66(5), 611-619.

Miyazawa, T.; Koso, S.; Kunimori, K.; Tomishige, K., Glycerol hydrogenolysis to 1,2propanediol catalyzed by a heat-resistant ionexchange resin combined with $\mathrm{Ru} / \mathrm{C}$, Applied Catalysis A: General, 2007, 329, 30-35. 